\title{
2 The Human Body as Material Culture - Linköping Cathedral Churchyard in the Early Modern Period
}

\section{Introduction}

This article discusses the human body as a kind of material culture, an active medium for expressing values and beliefs, as well as hopes for the life after this. The excavation of the cemetery at Linköping Cathedral in 2002-2003 comprised 570 individuals from the period 1100-1810. Here we have a unique opportunity to study living conditions and changes in mortuary practice over a long period

The material has been stratigraphically divided into three medieval phases (1-3) and three post-medieval phases (4-6). The period from circa 1500 until the end of the 17th century (phase 4) saw a distinct continuity in burial traditions from the Late Middle Ages. The great change actually came in the 1680s, when burial customs became much more heterogeneous. Arm positions were allowed to vary, the deceased was buried in normal clothes and it became much more common to put personal belongings in the graves. Phase 6 comprises the period 1780-1810, which is characterized by the introduction of a linear system, with burials taking place as deaths occurred, with no consideration for family, gender, social status etc.

Finally, the material is discussed in terms of specific themes: cemetery users, the cemetery as a social arena, and changes in mortuary practice. The change in grave ritual at the end of the seventeenth century can be interpreted as an expression of a more individual attitude to the human body and the grave as a social medium. The time around 1700 was a watershed between the united church of Sweden's Age of Greatness, perceived as the obedient instrument of the absolute monarch, and the more open attitude of the Age of Liberty, when new revival movements such as pietism began to gain influence, with their more personal and individually coloured faith. Recent studies in contemporary micro-rituals concerning changing modern grave rituals, indicates that the material culture as well spatial arrangements involved are very important for the new habits. It is possible to interpret these detectable changes in the material culture as an example of the concept of modernity and a desire of expressing new attitudes of individuality towards the deceased.

Material culture has for a long time been an important subject for cultural historians and not least archaeologists. When archaeologists and cultural historians discuss material culture it is frequently a matter of clear and manifest remains. But even the human body can be seen in the same way - as a social project, the most intimate and personal such venture. Through the body we communicate our identity 
and how we want our environment to apprehend us. We hide and we assert ourselves precisely with the body as the means, in life as in death. At the same time, the body is a meeting-place for all kinds of contradictory messages. We shape - or forbear to shape - our bodies according to ideals we may not always sympathise with (Hamilakis et al., 2002; Tarlow, 1999a, 2002b).

Latter-day research has emphasised the human's range of choices and capacity for expression. The history of the body is in many cases the history of the individual's relationship with the world around, for good and ill. We can see the body as an arena for differing interests, sometimes in the form of economic and social pressures, political power or the desire of commercial forces demanding that we appear in a particular way. In this way the body becomes a discursive field where different volitions meet and are reshaped (Foucault, 1998). At the same time the individual body carries the memory of our biological life and social history. The human body can be compared to an osteological database, with clear traces of the individual's conditions of life, health and illnesses, which in their turn reflect social distinctions and changes over time. The question is how factors such as life-span, child mortality and maladies in general have changed over time and how these factors can be interpreted as differences in human living conditions (Arcini, 1999; Arcini et al., 2012).

The dead body is a particular field for transformation. Through the treatment of the body after death and in the grave, a remodelling and communication occurs with the surrounding world which is not always in agreement with the deceased's own identity and volition. Here a transformation takes place which is frequently dependent on the wishes of the collective, the authorities or by convention. The grave can reflect the identity and social position of the deceased, but often it is even more an expression of the wishes and intentions of the surviving relatives (Tarlow, 2002a).

The following article deals with the view of the human body and Christian burial customs during a period of radical change: the Reformation and the break-through of modernity. The starting point is taken from an archaeological investigation in the cemetery of Linköping Cathedral in southern Sweden (Fig. 2.1). The cemetery functioned continuously circa 1100-1810 and the investigation in 2002-2003 comprised burials from the whole period. For Swedish circumstances, and even internationally, this investigation seems almost unique in capturing the whole sequence of burials over a 700-year period. The material is of special significance in that burial customs and osteological information can be analysed in an unbroken sequence for both the Medieval and the Early Modern periods. 


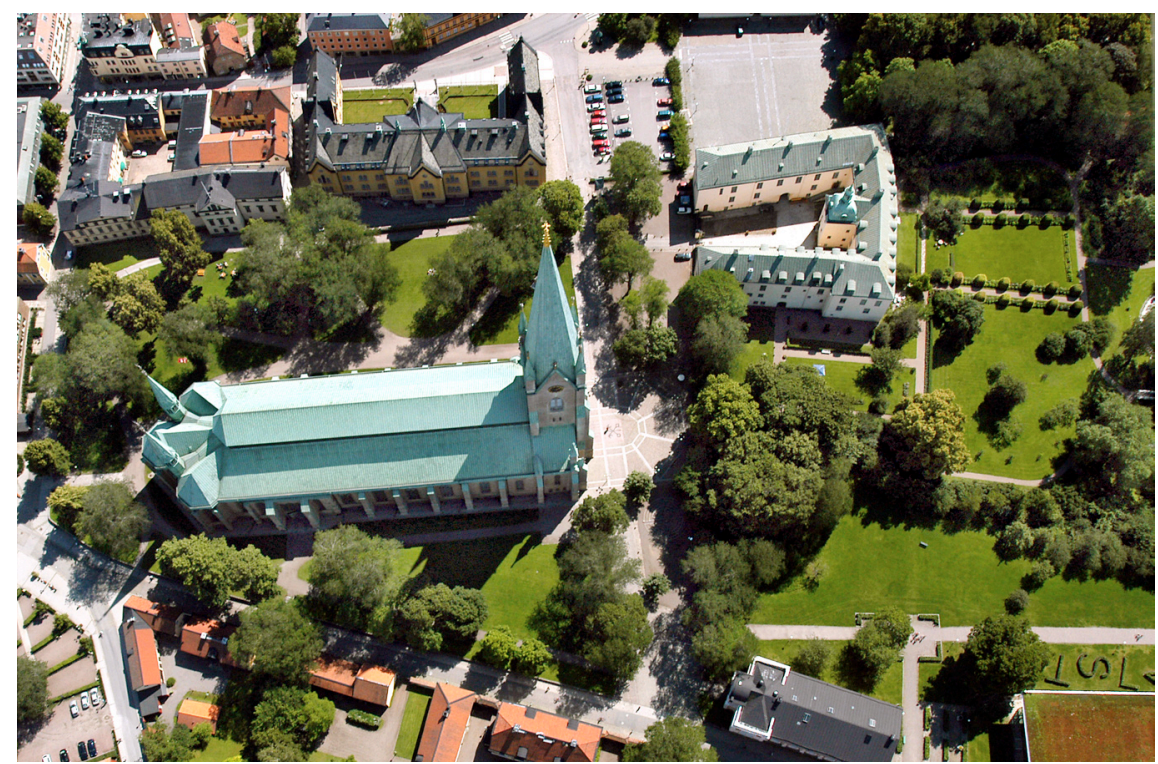

Figure 2.1: Linköping Cathedral from the air. Photo: Göran Billeson.

\subsection{Previous Research}

Research about medieval churchyards has a long Swedish tradition, where questions of burial customs and health matters have been in the forefront. Research has principally focused on cemeteries from the Middle Ages, with questions about the social change in burial customs in relation to changes in the composition of the population and social integration (Redin, 1976; see also Arcini \& Tagesson, 2005; Cinthio, 2002; Kieffer-Olsen, 1993; and further literature referenced here). Another prominent theme in cemetery research is how health and living conditions are reflected in the human osteological material (Arcini, 1999, 2003; Gejvall, 1960). An interesting theme has recently focused on burials outside ordinary and respectable society, temporary burial places during periods of plagues and other diseases, burials outside churchyards and at places of executions (Arcini et al., 2006; Carelli, 1995; Fendin, 2008).

If the number of large and small investigations into medieval churchyards has been great inside and outside Sweden, corresponding research into later ages has been much less (Arcini et al., 2006; Jonsson \& Nordström 2003; Stibéus, 1998). In England the extensive examination of graves from Spitalfields in London has attracted great attention, with incredibly well-preserved and accurately dated material from 1729-1852 (Molleson \& Cox, 1993; Reeve \& Adams, 1993). These investigations are important, but mainly provide isolated analyses without the possibility of comparison over time. 
On the other hand, there is copious literature about burial customs and burial art during the post-medieval period, mainly based on art-historical, historical and ethnological material, from a Swedish (e.g. Hagberg, 1937; Lindahl, 1969) and from an international perspective (e.g. Gilchrist, 2003; King \& Sayer, 2011; Litten, 1991). In his comprehensive survey of burial practices in the historic period, Harold Mytum treats the material culture of cemeteries and graves in early-modern and modern times from a broad cultural history perspective. He is at the same time forced to conclude that the opportunity to study changes in burials in the archaeological material is very restricted in England and North America, as large-scale investigations are broadly absent (Mytum, 2004). Given this background, the investigation in Linköping appears very special, with the opportunity to study changes in the cemetery over a long period with material virtually unique in the European context.

The investigation in Linköping during 2002-2003 has been previously presented in other publications (Fig. 2.2). The graves have been analysed from their stratigraphical position in the churchyard and with respect to relative chronology, facts which form the basis for discussion on the change in burial customs. Here, above all, a stratigraphical analysis with regard to the position of the arms in the graves, according to the Swedish scholar Lars Redin's classification (Redin, 1976), has been compared with the prevalence of graves with or without coffins. This resulted in a classification into six phases, three medieval and three from early modern times. The osteological investigation was realised in two stages (Arcini \& Tagesson, 2005; Tagesson \& Westerlund 2004). An extensive analysis has been carried out over the last year to ascertain the identity of the graves and thereby permit the osteological data to be related to the preserved church registers (Arcini, 2008). Lately, the material has been used for analysing an increase in stature during the Early Modern period in Sweden (Arcini et al. 2012).

\subsection{The Cemetery as a Social Arena}

The results of the investigations have been discussed previously, inter alia proceeding from analysis of the users of the churchyard and the cemetery as a social arena. Our study has shown that the cathedral churchyard was used by different individuals and social groups during different periods, which can be studied in the composition of the graves as regards sex and age. The somewhat clear differences in the medieval material have been placed in relation to the development of Linköping, initially a purely ecclesiastical regional centre, which in the later medieval period came to be an ever more composite urban community (Arcini \& Tagesson, 2005).

After the Reformation the cathedral became a parish church alongside the older parochial church of St. Lars, at the same time as the town declined in importance. Post-Reformation, the social composition of the cemetery must have changed radically. The churchyard came to function as a parish cemetery, presumably with 


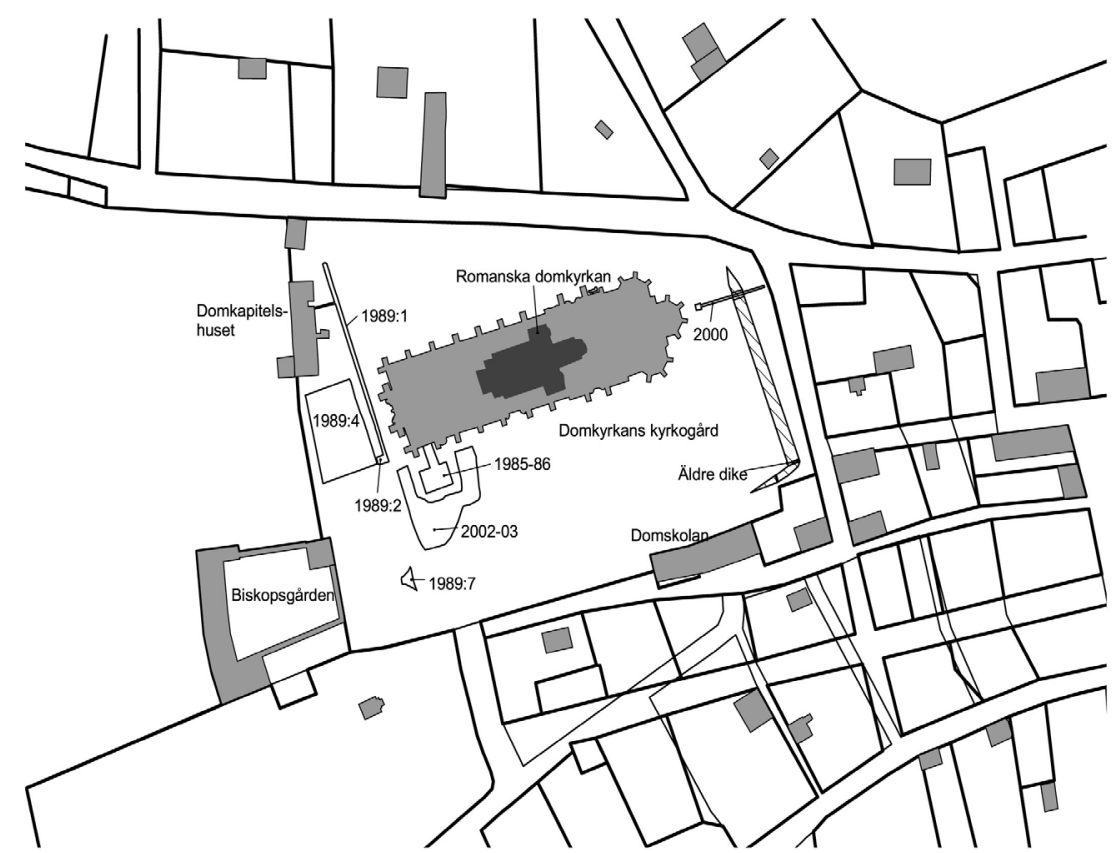

Figure 2.2: The Cathedral precinct, with the site of archaeological investigations in $1985-86,1989$, 2000 and 2002-2003. The black continuous line represents plot boundaries according to the map of 1696 . Dark shading shows medieval stone buildings, thin lines correspond to reconstructed medieval plot boundaries and streets. Graphics: Göran Tagesson and Lars Östlin, RAÄ.

a broader range of users as a result. At the same time, many family graves and grave monuments inside the cathedral from the 16th and 17th centuries indicate that the cathedral continued to have high status as a place of burial. Whether this also applied to the churchyard is an open question. Several scholars have been of the opinion that the cemetery in general declined after the Reformation, with social equalisation and degradation as a result (Lindahl, 1969, pp. 101ff; Troels-Lund, 1984).

In a recent seminar paper at Linköping University, the question of the social differentiation of the cemetery and in the cathedral was treated for the years 1695-96, based on meticulous entries in Linköping's death and burial register. The distribution of men, women and children varies to some extent in the different zones of the churchyard, as does that for different social strata. The identified persons can also be compared with the detailed cadastral map of Linköping from 1696, and in many cases there is agreement between the social position of the burial location in the churchyard and that of the location of the homestead in the town. For the cathedral there is a grave map from 1722, where the price of graves in different positions is clearly indicated. It is obvious that the most easterly graves were the most expensive, with 
the price decreasing the further west one moved. Altogether, however, this analysis shows that the social variation between occupation/title, land tenure in the town and grave-position in the churchyard is not unequivocal (Nyström Tagesson, 2006). The grave as a social marker and as material culture is thus not a direct reflection of social and economic conditions. They can be interpreted as the result of many different factors - as a social strategy.

In 1751 the burials at the other church in Linköping, St Lars, ceased and the cathedral churchyard became the town's only cemetery. There was a clear tendency for an ever larger area of the churchyard to be used for burials. Graves that can probably be associated with the last phases have been found in the south-western part of the cemetery. The area south of the cathedral was however far too small. As early as 1789 we find information that the cemetery was full, and suggestions were made also to use the area north of the cathedral. This indicates that burials north of the church were not customary in older times (Hassler, 1976; Nyström Tagesson, 2006).

In the 1780s a linear grave system was introduced in the cemetery, which means 'that all bodies to be buried in the cathedral churchyard should be ordered one after the other without consideration of parish, social status or age' (Hassler, 1976, p. 24). By this time society has broadened and the social topography of the cemetery become wholly egalitarian, with high and low status graves intermixed. We can see clearly that this applies to the most recent generation of graves, where men and women, children and the old lie mixed with each other. The occurrence of a number of graves with wrought-iron coffin handles indicates the presence of graves of higher status. The family graves inside the church were, however, in continued use until the 1810s.

At the same time we should not forget that social status could be expressed through the increasingly common use of gravestones. In that way we can say that development proceeded from an older period with egalitarian graves but with a clear social topography in the cemetery. This changed in the Early Modern period, where the location in the churchyard had played out its role, while the individual grave and the gravestone alone had to express social status and identity. Thus during the whole period from 1100 to 1811 we see a continuous process, in which the users of the cemetery changed from being an almost exclusive circle of clerics in the Early Middle Ages to becoming a burial ground for members of increasingly different and broader social strata. This indicates that the development in Linköping goes from a medieval situation with several churchyards, each with a homogeneous social or cultural composition, to ending up with a single but more heterogeneously-populated cemetery (cf. Mytum, 2004, p.17; Sayer, 2011, pp. 202, 210).

At the same time, the development reflects in an interesting way large and revolutionary events in the little town, with a progression from an apparently complicated and heterogeneous social and religious milieu to one that is more homogeneous. It is clear that the tendency towards fewer churches and cemeteries represents an important medium for social control, which in time made possible an effective tool for state absolutism and an appurtenant orthodox unitary church. 


\subsection{The Grave and the Individual}

The burial customs in the cathedral cemetery, reflected in the Middle Ages in the positioning of the arms and the absence of personal items, are totally in accordance with those observed by Lars Redin in Skanör, namely that the arm positions show a very homogeneous picture and that they are contingent on chronology (Redin, 1976). The oldest graves had the hands parallel with the sides (A-type), while during the High Middle Ages they were folded over the pelvis (B-type). During the Late Middle Ages the arms were laid over the abdomen or up towards the chin (C- and D-type). Interestingly enough, these late medieval types were shown to be in use some time after the Middle Ages. We can even distinguish a quite new type of arm position, called type E, with the arms along the sides, the hands laid at an angle on the hip-bone and the lower arms below the iliac crest of the hip (Figs. 2.3 to 2.5).

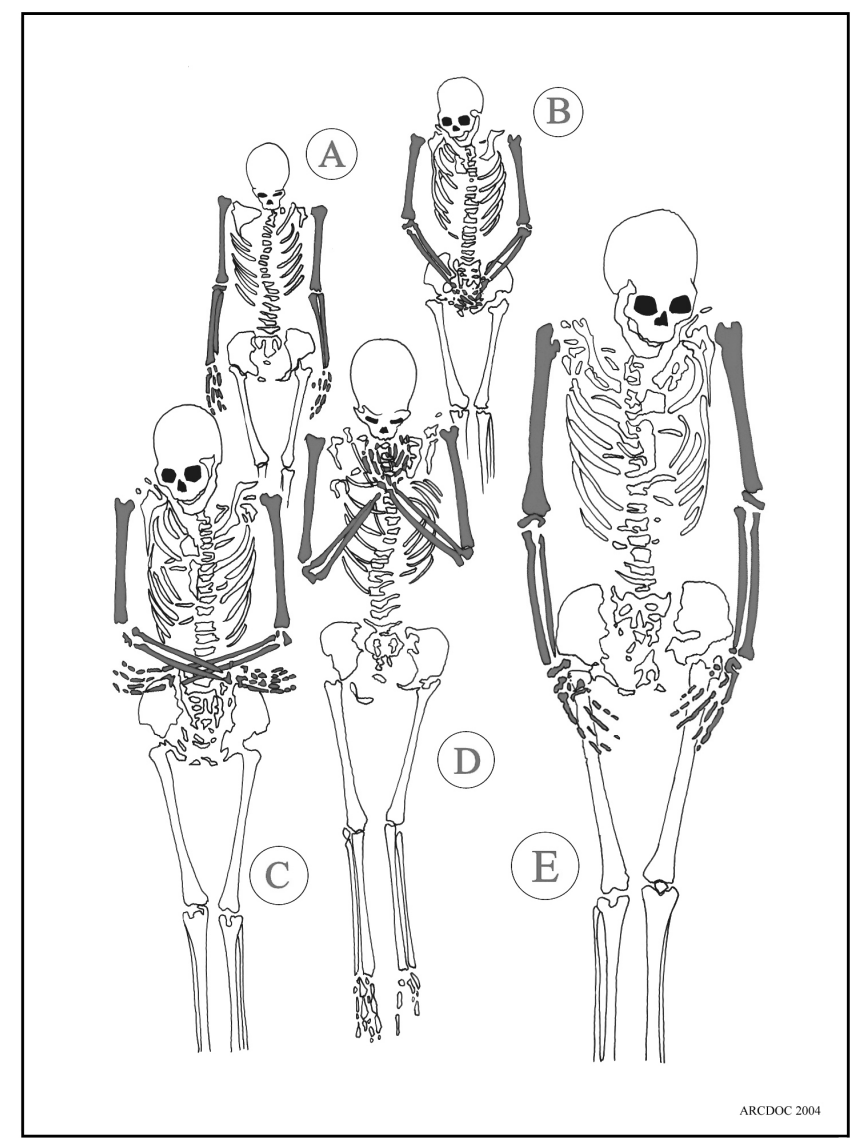

Figure 2.3: Arm position types A-E. Drawing Richard Holmgren, ARCDOC. 


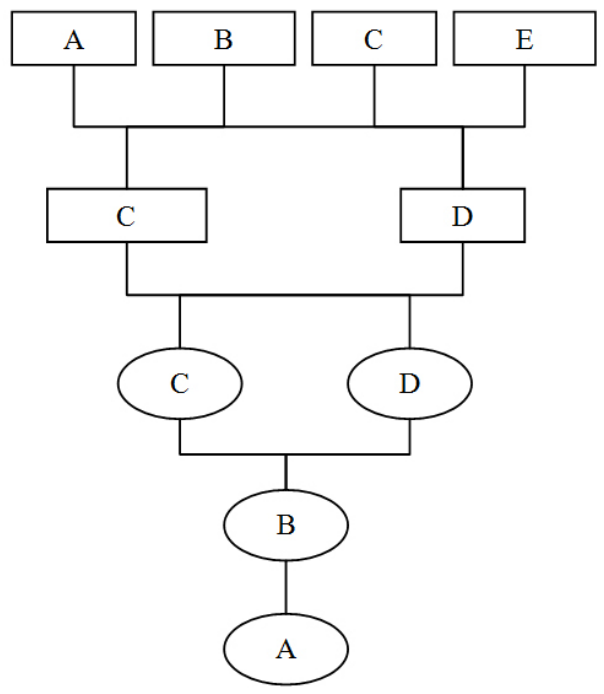

Fas 5

Fas 4

Fas 3

Fas 2

Fas 1

Figure 2.4: Stratigraphic matrix of grave types distributed by phase. Oval indicates burial without coffin, rectangle wooden coffin. A-E correspond to arm position types.

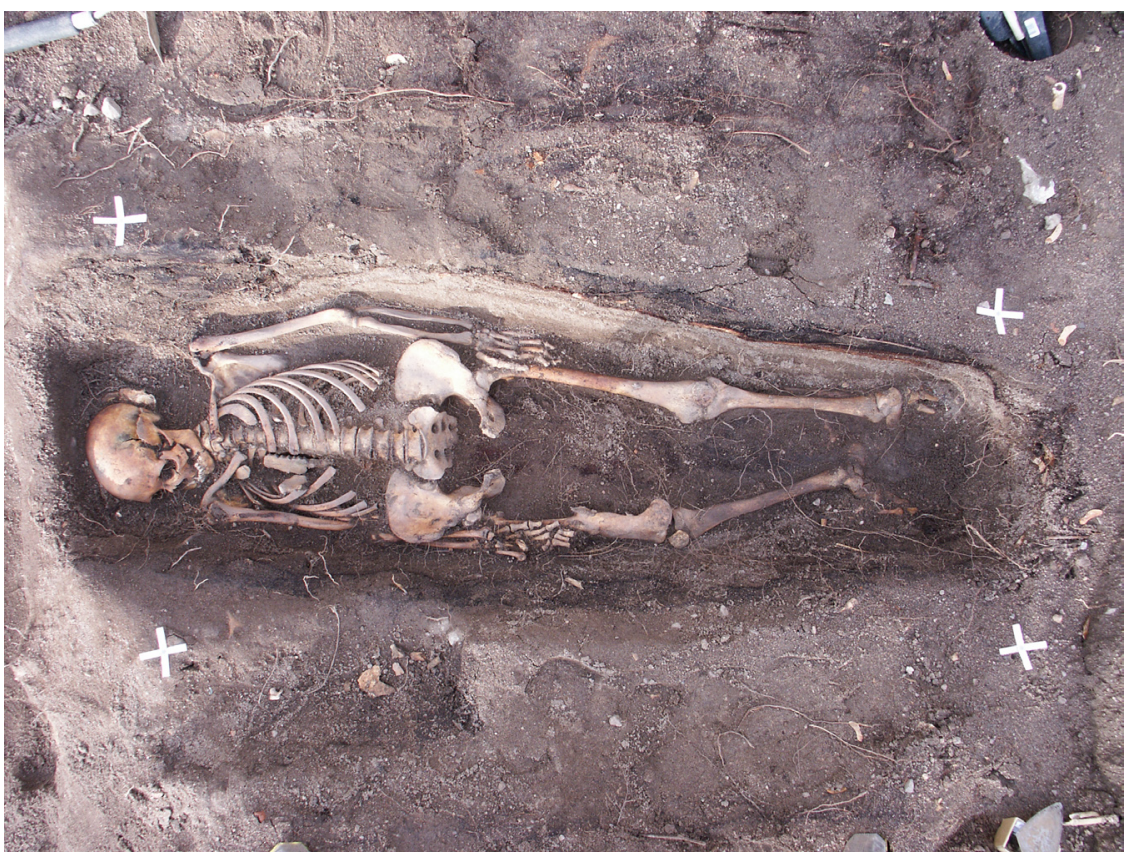

Figure 2.5: Grave from phase $6,1780-1810$, in wooden coffin with arm position E. Photo: RÄ̈. 
In the analysis of the cathedral churchyard graves it has emerged that burial customs underwent change, shown partly through the different arm positions and coffin shapes during different periods, and partly in the degree of homogeneity. The customs have been established as particularly homogeneous during all periods up to the end of the 17th century. It is true that a great change occurs between phases 3 and 4, in that wooden coffins were introduced in all graves. It is not clear when this change took place, possibly during the 16th century (Fig. 2.4). The use of coffins can be conceived as a form of container, where the body rests without being mingled with dirty earth and with other individuals. During the same period an increase in, and wider social spread of, the use of gravestones occurred. These can also be seen as a sort of lid over the graves, to prevent them being dug asunder or intermixed. This shows that during early modern times increasing importance was placed on the individual and the sanctity of the body.

Several British scholars have discussed the same tendencies and interpreted them as a change in the relationship between the living and the dead. After the Reformation the situation of the deceased could not be influenced by intercession. The funeral changed in importance to emphasise a taking leave of and a consigning of the deceased to God. The distance between the dead and the living came to increase drastically after the Reformation, and the grave came to be reduced to an expression of the memory of the dead person. Parallel with this, the body became increasingly important as the centre of the individual personality and the identity of the deceased. The body's decomposition became ever more problematic, which is clear from various measures to preserve the grave and the body intact (Gilchrist, 2003; Litten, 1991, pp. 32ff; Tarlow, 1999a, 2002). In funeral art this change is evident. Ever greater care is devoted to the memory of the dead and the grave comes to express personality, status, birth and economic standing (Lindahl, 1969; Mytum, 2004).

In the cathedral cemetery, phase 4 (16th century to 1680s) represents a continued extremely homogeneous and uniform burial style. We could interpret this as the result of a long tradition with a very set and strict way of treating the dead. Several scholars have wished to interpret the arm positions in eschatological terms (e.g. Cinthio, 2002). Such an interpretation proceeds from the belief that the survivors in the preparation of the deceased gave expression to collective thoughts about life after death. This underlines that the individual during the Middle Ages and for a period in early modern times should first and foremost be seen as part of a collective, where it is the theological and popular image of life and death prevalent at the time that means more than the individual. We can at the same time assume that a uniform burial tradition has manifested itself. In funeral art a continuity and conservatism in the framing of graves in the early Reformation period has previously been noted (Lindahl, 1969, pp. 65ff; Mytum, 2004).

In connection with phase 5 , however, grave practices were radically changed, in that a greater variation in arm positions was allowed. This change, thanks to numismatic dating, we can say began during the 1680s, and may be interpreted 
in terms of a more individualized burial practice (Arcini \& Tagesson, 2005, p. 298). This chronological framework seems to be unique in Sweden; no other excavation covers the total period from the Middle Ages up to the Modern period. An ongoing major archaeological project in the Swedish town of Nya Lödöse (next to present day Gothenburg) seems to underline the tendencies in Linköping. The cemetery of the town church covers the period from the late 15th century till the 1630s, and has so far revealed about 700 individual graves. A very preliminary interpretation shows that almost all of the graves are lacking traces of coffins, and comprise a rather homogenous grave ritual according to the uniform arm positions and lack of personal items (pers. comm. Dr. Christina Rosén).

The alteration at the Linköping cemetery has possibly to do with a change in how the deceased was prepared for burial, perhaps clothed and made presentable for the mourners to say their goodbyes, which in later times was called 'viewing the body'. During the Catholic period burial took place as soon as possible after death, but after the Reformation there was a tendency towards an ever longer preparation process. This came to have a social dimension: the longer the time between death and burial, the higher the social position (Lindahl, 1969, pp. 84ff; Troels-Lund, 1984, pp. 83ff). The long preparation time of course left room for greater care of the dead and thus allowed for individual variations.

At the same time we see an interesting change whereby it becomes much more common for the dead person to be buried in his or her day clothes. We have found buttons and remains of clothing that indicate this (Arcini \& Tagesson, 2005, p. 299). In other contexts, including from Spitalfields in London, as in ethnological records in Sweden, there is evidence of special burial vestments (Hagberg, 1937; Reeve \& Adams, 1993, pp. 104ff; Troels-Lund, 1984, pp.117ff). This custom has recently been observed in the very northern part of the Swedish kingdom, at the cathedral cemetery in Oulu (present Finland), dated from the 17th century to the 1780s, where many of the deceased had simple burial garments or were covered with a shroud, in special cases also in their daily clothes (Lipkin \& Kuokkanen 2014). Remains of special burial clothes, e.g. half a slipper, were also observed in a burial chamber in Kalmar domkyrka in 2009 (Ohlsson 2010) and in the Royal Naval Church in Karlskrona (Nyberg 2010).

Conditions are not propitious in Linköping for the preservation of organic material, but there is nonetheless much to indicate that the textiles found in the investigation, interpreted as day clothes or special burial garments, was getting more common from the end of the 17th century onwards (Lundwall, 2006).

During this period the number of objects in graves also notably increased ( $c f$. Mahoney-Swales et al., 2011, p. 223). It can be a matter of personal belongings such as jewellery which accompanied the dead person, for example rings and earrings, but also other rather odder objects, such as a clasp-knife, clay pipes and even a snuffbox (Fig. 6). Even in the plague cemetery of Pestbacken in the province of Blekinge (southern Sweden), a large number of the dead were buried in their ordinary clothes. It has been suggested that plague victims had to be quickly buried with their clothes 
and personal belongings as people were afraid of contagion (Arcini et al., 2006), a supposition that could also apply in the case of Linköping. It does not however explain the fact that graves with clothing and personal effects are not found in older phases. Probably it is after all a case of change attributable to altered burial customs.

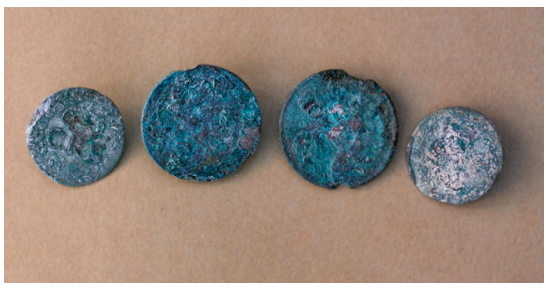

(a)

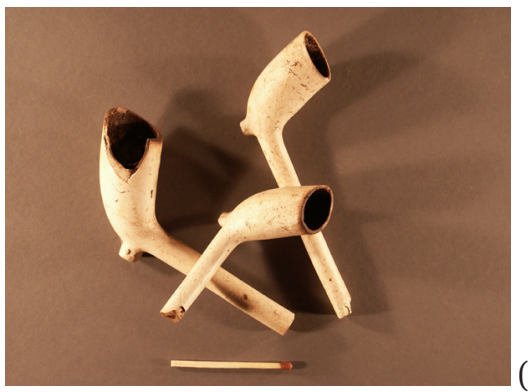

(b)
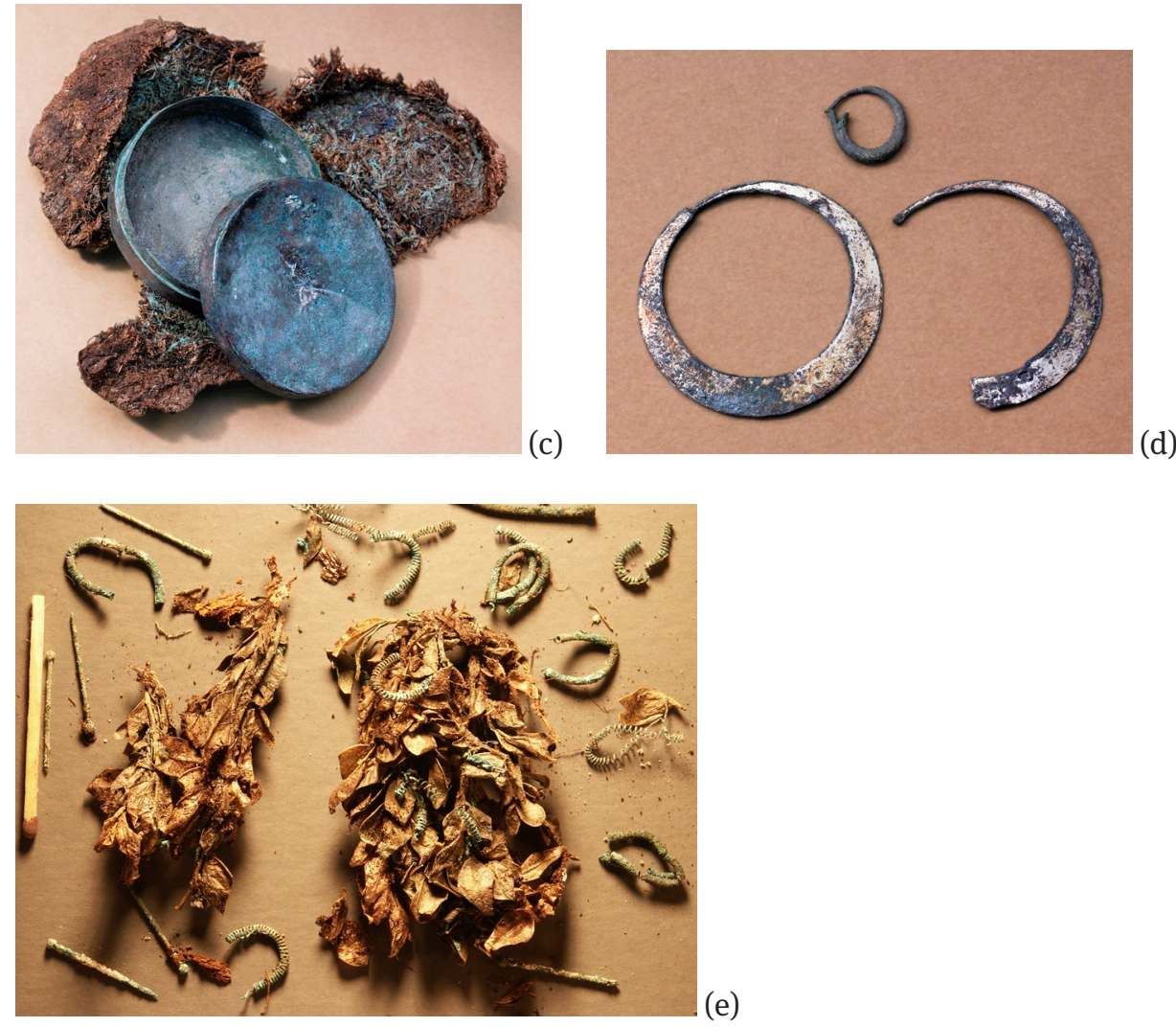

Figure 2.6: a-e. Four coins from graves, dated to 1665-1670/4. Finds in graves from phase 5-6: clay pipe, snuff box, gilded silver earrings, and fragment of burial coronet. Photo: Göran Billeson. 
A further phenomenon is the many funeral coronets that are found in graves from this period. These consist of wreaths and flowers, often with intertwined copper threads and glass beads, in isolated cases even gilded. From later periods we know that coronets were above all given to girls and young unmarried women, who according to tradition were consecrated Brides of Christ. In our material it is obviously mainly girls and women who are associated with these coronets, even quite new-born girls. Thanks to these investigations we can now say with certainty that these coronets first came into use at the end of the 17th century. The custom that small dead girls were dressed as Brides of Christ was opposed during the 19th century by the church authorities, but proved to be difficult to stop. It is clear that here we are dealing with a manifestation of popular customs, which during just this period had the chance to flourish (Hagberg, 1937; Troels-Lund, 1984, pp. 126ff). A somewhat similar tradition is the maidens' garlands, well known and recorded in most parts of Britain and in other parts of Europe, made in the shape of a bell and used on the funeral coffin and later hung in the church. This tradition is dated to the Early Modern period and later, and was used at funerals to celebrate the lives of those who died in a 'state of virginity' (Morris, 2011).

Nyberg has noted that burial coronets in the Linköping material have also been found in some men's graves (Nyberg, 2005). This means that coronets could be given to children and unmarried adults of both sexes, which has also been observed in other cases (Hagberg, 1937, pp. 185ff). The grave material is interpreted in relation to the change in gender roles in the Early Modern period, where among other things the modified importance of marriage has previously been observed. The occurrence of finger rings can be interpreted as an expression of the growing importance of marriage during this period, at the same time as Nyberg wishes to interpret the personal objects, jewellery and clothes as a stage in showing care for the individual by making death less repellent (Nyberg, 2005; $c f$. Tarlow, 1999a).

In the graves in Linköping, traces of moss, straw and other organic material has been observed, but not yet fully analysed. This phenomenon has recently also been observed in the urban grave material from Nya Lödöse (pers. comm. Dr. Jens Heimdahl). This is also well known in aristocratic graves. In the coffins in the Soldan burial vault at Sura church, dated to the 18th century, the body was placed on a bed of sawdust and hay (Jonsson 2009, p. 135f), and in the graves of the family Brahe on Visingsö, traces of hops, herbs and roses were found in the coffins in the grave vault in Brahekyrkan, These may have been placed in a cushion or mattress, interpreted as a masking of the odour from the corpse in order to make the death more beautiful (Nyberg 2010; 2013, p. 267).

The historian Ann-Sofie Arvidsson has also shed light on these questions in her dissertation about church and state authorities and their relations to death and mourners. On a superficial level, there are no significant changes in the funeral liturgy during this period that could easily explain the profound changes in the treatment of the corpses. However, Arvidsson stresses the fact that the preparation of the corpse 
was a task for the relatives and the survivors. In the new church law of 1686, the priest was even prohibited from being present at the 'utfärdsbönen', i.e. the praying before taking leave from the house for the funeral act in the church. According to the author, this gives the mourners and relatives greater influence on the preparation of the body, and diminishes the influence of the church on these intimate tasks (Arvidsson, 2007, pp. 237ff). Arvidsson, who discusses the results from Domkyrkoparken in Linköping, wants to explain the changes in terms of diminished liturgical control, which would let older vernacular traditions come to the surface. This theory is interesting, but in my opinion not quite appropriate. We have no indications that personal items or the use of personal clothes in graves could have been a sort of suppressed folk tradition. The gap between pre-Christian habits and recorded changes in the Swedish 17th century is at the same time too big.

In my opinion, these changes do not concern only a change in burial custom as such; they must also imply a radical alteration in the view of what the individual represents. During the Early Modern period, the human body undergoes a change from being part of a collective to becoming an individual who can be ascribed particular attributes and personal characteristics (Tarlow, 2002a). The change, during the late Middle Ages and the Early Modern period, from only being a corpse collectively awaiting the Resurrection, to becoming a body representing an individual - for example a smoker or an official - is radical in a thorough-going way.

It can also be useful to compare these alterations with similar contemporary tendencies. The Swedish theologian Jan-Olof Aggedal has studied modern grave rituals and notices an increasing tendency to move from a strict and uniform use of funeral shrouds towards the use of personal clothes and even placing personal items in the coffin. Furnishing the coffins with personal objects, such as teddy-bears, wedding rings etc. was previously opposed by the church, and as late as the 1990s considered as inappropriate in some districts, but today it is more widely permitted. Aggedal discusses these habits as micro-rituals within a broader, more official macroritual, and stresses the importance of the personal and private meeting between the dead and those left behind: an opportunity and a moment for bidding the dead goodbye. This may be understood partly as a more permissive attitude from the Church and the undertakers, partly as a way of making possible personal expressions of the personality of the deceased, a way of telling that the she/he is not anonymous, but still a unique person (Aggedal, 2006).

The act of taking leave, as well as the placing of personal objects in the coffin, may be understood as a very private and important act, and the objects, clothes and spatial arrangements as meaningful and with strong attachment to the dead person. The changes observed in the grave material from the 17th century as well as from contemporary analysis may be understood against the background of profound sociocultural changes in society. But in both cases, the new micro-rituals of expressions of personal connection between the dead and those left behind, are made possible within the changed macro-rituals, i.e. the enabling of a private moment, as well as the 
absence of any officials at this moment. These results also points out the importance of the material culture, as observed in the archaeological record and the contemporary analysis, as extremely important, not being just a reflection of changing mentalities, but instead a very active medium of these mentalities.

\subsection{Into an Early Modern Culture?}

The change in burial practice has been proved to begin during the 1680s and in itself seems to be a paradox. The 17th century was a time when Sweden enjoyed Great Power status, and a period when the Church was seen as a strong and cohesive factor. In scarcely any other period of our history have the church and state cooperated to such a high degree - one faith, one church and one king. Vicars around the country were one group among many civil servants with the task of influencing the local populace in both private and public affairs. As one scholar has expressed it, religion became the cement that consolidated unity both inwards and outwards. During the 17th century Sweden became an even more homogeneous state, where the only permitted creed was seen as decisive for cultural and political unity in the country (Villstrand 2011, pp.324ff).

Under the king Karl XI (1660-97) many of the centralising tendencies of the age came together. The absolute monarchy was effectuated at the Riksdag (parliament) of 1680 and the supremacy of the state over the Church was confirmed by the church ordinance of 1686. During the same period, too, a series of ecclesiastical books appeared - such as a new catechism in 1689, a church handbook in 1693, a new hymnbook in 1695 and finally King Karl XII's Bible in 1703 - all examples of the monarchy's view of the Church as an effective moulder of public opinion and of the role of the state as the Head of the Church (Montgomery, 2002, pp. 140ff, 156ff).

Tendencies to a more personally-tinged religiosity were however present during the whole of the 17th century, through the pious prayer books and other religious tracts that were published. During the later 17th century influence began to be felt from evangelist movements in Germany, above all Pietism, with its emphasis on the individual's relationship to God. It was primarily in the educated middle class in the larger towns that these new ways of thinking gained a foothold, a development which brought in its train a questioning of the established social order. During the period up to and including the first half of the 18th century, however, these tendencies were strongly opposed and their proponents imprisoned and persecuted. It was not until the 18th century, under the influence of the fall of the absolute monarchy after the death of Karl XII in 1718 and the later Enlightenment, that these ideas gained greater currency (Lenhammar, 2000; Montgomery, 2002, pp. 62ff, 171ff, 180ff; Mansén, 2011: 411ff).

The second half of the 17th century thus embraces an absolute and autocratic monarchy combined with a church whose task was to legitimise the ascendancy 
and act as a tool for uniformity in religious life. The position of the priesthood came to be strengthened during this time, in their role as the monitors of both morality and orthodoxy in the local community. More recent research however shows that the strong state authority and the Lutheran church scarcely succeeded in changing people's consciousness in depth (Villstrand 2011, p. 334ff). For example, the Swedish historian Göran Malmstedt has shown in his studies that a popular, almost medieval, religious mentality persisted, and not until the 18th and 19th centuries was it replaced by new 'modern' conceptions of the difference between sacred and profane, holy day and weekday, and how one should behave in the church (Malmstedt, 1994, 2002).

It is thus hardly a few simple changes in the prevailing ideology or church tradition that had an obvious effect on the form of the graves in the cathedral churchyard in Linköping. At the same time, there are clear tendencies in 17th-century society that point forward towards a new view of society. Changes in town planning and building practices are well-known phenomena which are often interpreted in this direction. In the 1650s, the important medieval harbour- and merchant town of Kalmar in southeastern Sweden, at the border of Denmark, was moved to an adjacent island, on which a very modern, strictly geometrical town-plan was constructed (Tagesson 2013), and after the devastating fire in 1655 , the town of Norrköping came to have an entirely new town plan of gridiron pattern according to Renaissance ideals (Hållans \& Tagesson, 2003, pp. 13ff). Even Linköping had some share in this in the 17th century when the new, straight Storgatan (the High Street) was drawn through the town down to the new bridge of Stångebro (Tagesson, 2002, pp. 166ff).

The Swedish scholar Nils Ahlberg has shed light on this process of town-plan reformation during the Early Modern period. Ahlberg points out that this process was very decisive and involved almost all towns in Sweden and Finland, and also in the Swedish provinces elsewhere in the Baltics. The introduction and accomplishment of large-scale Renaissance-style town-planning was without counterpart in contemporary Europe, and must be interpreted as an important mental change in the society (Ahlberg, 2005).

At the same time there are clear examples of a new housing culture gaining ground in both towns, seen most clearly in that the dwelling-house moved to a more exposed position on the street boundary of the plot. Other contemporary phenomena are the separation of the kitchen from the dwelling, the appearance of windows and chimneys, and also changes in the combination of crockery (Ersgård, 2003; Hållans \& Tagesson, 2003, pp. 13ff; Tagesson, 2002, p. 198, pp. 260ff).

These tendencies have been characterised as a culture of separation. Former prominent collective features in dwelling habits and mealtime customs diminished, at the same time as the appearance of a greater number of rooms, chairs, forks and so on can be interpreted as an increased awareness of the importance of the individual. Several scholars have further pointed out that the emphasis on the façade and the exterior, in both houses and people, came to be ever more important as the outer manifestation of the inner (Johnson, 1996; Rosén, 2004, pp. 255ff; Rosén, 2006; West 
\& Tarlow, 1999). The boundary between the private and the public becomes clearer in these examples, and thereby the possibility and the desire to display the private sphere in relation to the public space increased.

Developments were not unequivocal, however. Many of the examples of individualistic features indicated above first became more discernible in the 18th century. In a famous study, the Nestor of American archaeology, James Deetz, rather pointed to the mid-18th century as the decisive breakthrough period for an individualised world view (Deetz, 1996). A number of features of the Nordic housing culture also clearly first make their impact during the 18th century (Erixon, 1984, pp. 58ff, 77; Rosén, 2004). In his major review of cemetery culture in recorded times, Mytum showed that many late burial traditions were already established during the 17th and early 18th centuries, but it was not until after the mid-18th century that they gained general currency, and the development and professionalization of burials and churchyard culture achieved their major penetration (Mytum, 2004). Similarly, the tendencies that Tarlow noted respecting the changed view of the body and the body's dissolution in the Early Modern period can chiefly be attested during the 18th and 19th centuries (Tarlow, 1999b; Tarlow, 2002a; Tarlow, 2002b).

\subsection{Conclusions}

The archaeological excavation at the cemetery of Linköping from 2002-03 still seems to be a rather unique material, due to its chronological framework, covering the long period from circa 1100-1810, and thus making possible analysis of changing grave rituals in a long time perspective. The beginning of a change in the direction of more heterogeneous burial customs, from a collective to a more individual mentality, including personal daily clothes, personal objects and varied arm positions, can be dated to the end of the 17th century, first observable in a grave from the 1680s. Some of the features, like the funeral coronets, have later on been understood as an expression of popular conceptions which were in conflict with the official view of the Church. The fact that these tendencies can be dated to a specific period, a time of strong unitary and authoritarian culture, suggests the emergence of a popular and individually shaped burial practice that could be articulated in the material culture of a churchyard.

Research into the process of change during early modern times has thus emphasised different aspects, where however one common feature is an increased stress on the individual at the expense of the collective. The time when this became visible is specified differently depending on the centre of gravity that different subjects and research traditions have. From this we learn that the birth of the individual and the growth of individuality are a complicated and long-drawn-out process. It is then all the more important that, in the archaeological material from the cathedral cemetery in Linköping, we can make these aspects more precise. 
The period was an age of transition, from the unitary church of the Great Power period, seen as the obedient tool of an absolute monarch, to the more open outlook of the Age of Liberty, when new evangelist movements such as Pietism began to gain influence, with a more personal and individually tinted faith. Recent studies in contemporary micro-rituals concerning changing modern grave rituals, indicates that the material culture as well as spatial arrangements involved are very important for the new habits. It is possible to interpret these visible changes in the material culture as an example of the concept of modernity and a desire of expressing new attitudes of individuality towards the deceased.

This article is a revised and updated version of a previously published text (Tagesson 2009).

English translation: Norman Davies, Linköping.

\section{References}

Ahlberg, N. (2005). Stadsgrundningar och planförändringar. Svensk stadsplanering 15211721. Acta Universitatis Agriculturae Sueciae. Agraria 2005: 94 . Uppsala: Institutionen för landskapsplanering Ultuna.

Arcini, C. (1999). Health and disease in early Lund: osteo-pathologic studies of 3, 305 individuals buried in the first cemetery area of Lund 990-1536. Archaeologia Lundensia VIII. Dissertation, University of Lund.

Arcini, C. (2003). Åderförkalkning och portvinstår. Välfärdssjukdomar i medeltidens Åhus. Arkeologiska undersökningar. Skrifter 48. Stockholm: Swedish National Heritage Board/ Riksantikvarieämbetet.

Arcini, C. (2008). Lacunae to fill: combining paleopathological and documentary research in investigations of individuals from a post-medieval Swedish cemetery. In: M. Brickley and M. Smith. (Eds.), BAR International Series 1743. Proceedings of the Eighth Annual Conference of the British Association for Biological Anthropology and Osteoarchaeology (pp. 85-92). Oxford: BAR.

Arcini, C. \& Tagesson, G. (2005). Kroppen som materiell kultur. Gravar och människor i Linköping genom 700 år. In A. Kaliff \& G.Tagesson, (Eds.), Liunga. Kaupinga. Kulturhistoria och arkeologi i Linköpingsbygden (pp. 283-317). Arkeologiska undersökningar. Skrifter nr 60. Linköping: Swedish National Heritage Board/Riksantikvarieämbetet.

Arcini, C., Jacobsson, B. \& Persson, B. (2006). Pestbacken. Lund: Swedish National Heritage Board/ Riksantikvarieämbetet.

Arcini, C., Ahlström, T., \& Tagesson, G. (2012). Variations in Diet and Stature: Are They Linked? Bioarchaeology and Paleodietary Bayesian Mixing Models from Linköping, Sweden. International Journal of Osteoarchaeology 2012. Published online in Wiley Online Library (wileyonlinelibrary.com) DOI: 10.1002/oa.2247.

Arvidsson, A-S. (2007). Makten och döden. Stat och kyrka möter svenska efterlevande under ett långt 1700-tal. Dissertation. Stockholm: University of Stockholm.

Carelli, P. (1995). We are not all equal in the face of death: profane graves in medieval Lund. Meddelanden från Lunds universitets historiska museum. 1993/1994 (10), 43-59.

Cinthio, M. (2002). De första stadsborna. Medeltida gravar och människor i Lund. Eslöv: Symposion. 
Deetz, J. (1996). In small things forgotten. $2^{\text {nd }}$ edition. New York: Anchor Books.

Erixon, S. (1984). Byar, gårdar och hus under Bjärka-Säby. Redigerad och kommenterad av Göran Rosander. Kristianstad: Nordiska museet.

Ersgård, L. (2003). Det dynamiska vardagslivet. In Karlsson, P. \& Tagesson, G. (Eds.), Tyskebacken. Hus, människor och industri i stormaktstidens Norrköping (pp. 16-27), Arkeologiska undersökningar, Skrifter 47. Linköping: Swedish National Heritage Board/ Riksantikvarieämbetet.

Fendin, T. (Ed.) (2008). Döden som straff: glömda gravar på galgbacken. Östergötland Fakta 7. Linköping: Östergötlands länsmuseum.

Foucault, M. (1998) [1974]. Övervakning och straff. Fängelsets födelse. (trans. C. G. Bjurström). Lund: Archiv Voirlag.

Gejvall, N-G. (1960). Westerhus. Medieval population and church in the light of skeletal remains. Lund: Kungl. Vitterhets Historie och Antikvitets Akademien.

Gilchrist, R. (2003). 'Dust to dust': Revealing the reformation dead. In D. Gaimster \& R. Gilchrist (Eds.), The Archaeology of Reformation 1480-1580.(pp. 399-414). Leeds: Maney.

Hagberg, L. (1937). När döden gästar. Svenska folkseder och svensk folktro i samband med död och begravning. Stockholm: Wahlström \& Widstrand.

Hamilakis, Y., Pluciennik, M. \& Tarlow, S. (2002). Thinking through the Body. Archaeologies of Corporeality. New York: Kluwer Academic/Plenum.

Hassler, O. (1976). Kyrkogårdenberättar om det Linköping som var: Linköpings och St Lars griftegård 1811-1899. Linköping: Förf.

Hållans, A-M. \& G. Tagesson. (2003). I Tyskebacken. In P. Karlsson \& G. Tagesson (Eds.), Tyskebacken. Hus, människor och industri i stormaktstidens Norrköping. Arkeologiska undersökningar. Skrifter 47. Stockholm: Swedish National Heritage Board/

Riksantikvarieämbetet.

Johnson, M. (1993). Housing culture: traditional architecture in an English landscape. London: UCL Press.

Johnson, M. (1996). An Archaeology of Capitalism. Oxford: Blackwell.

Jonsson, K. \& Nordström, A. (2003). En tidigkristen gravplats och en medeltida kyrklämning. Gravar och kyrkor i Sura 900-1800. Västmanlands läns museum. Rapport 2003: A16. Västerås.

Jonsson, K. (2009). Practices for the Living and the Dead. Medieval and Post-Reformation Burials in Scandinavia. Stockholm Studies in Archaeology 50. Diss.

Kieffer-Olsen, J. (1993). Grav og gravskik i det middelalderlige Danmark - 8 kirkegårdsudgravninger. Dissertation. Aarhus: Univ. Aarhus.

King, C. \& Sayer, D. (Ed.) (2011). The archaeology of post-medieval religion. Woodbridge: Boydell.

Lenhammar, H. (2000). Sveriges kyrkohistoria. 5. Individualismens och upplysningens tid. Stockholm: Verbum i samarbete med Svenska kyrkans forskningsråd.

Lindahl, G. (1969). Grav och rum. Svenskt gravskick från medeltiden till 1800-talets slut. KVHAA. Antikvariska serien 21. Stockholm: Almqvist \& Wiksell.

Lipkin, S. \& Kuokkanen, T. (2014). Man buried in his everyday clothes - attire and social status In early modern Oulu. Focus on Archaeological Textiles: Multidisclipinary Approaches. Monographs of the Archaeological Society of Finland 3, p 40-53.

Litten, J. (1991). The English way of death. The common funeral since 1450. London: Hale.

Lundwall, E. (2006). Analysrapport textilfynd, Linköping, Domkyrkoparken. Antikvarisk-tekniska avdelningen, konservering av kyrkliga inventarier. Dnr 413-4313-2005. Stockholm: Swedish National Heritage Board/Riksantikvarieämbetet.

Mahoney-Swales, D., O`Neill, R. \& Willmott, H. (2011). The hidden material culture of death: coffins and grave goodes in late 18th- and early 19th-century Sheffield. In C. King \& D. Sayer (Eds.), The archaeology of post-medieval religion (pp 215-232). Woodbridge: Boydell.

Malmstedt, G. (1994). Helgdagsreduktionen. Övergången från ett medeltida till ett modernt år $i$ Sverige 1500-1800. Dissertation. Göteborg Univ. 
Malmstedt, G. (2002). Bondetro och kyrkoro. Religiös mentalitet $i$ stormaktstidens Sverige. Enskede: TPB.

Mansén, E. (2011). Sveriges historia 1721-1830. Norstedts svenska historia 5.

Molleson, T. \& Cox, M. (Eds.) (1993). The Spitalfields Project. Volume 2: the anthropology. The Middling Sort. CBA Research Report 86. London: Council for British Archaeology.

Montgomery, I. (2002). Sveriges kyrkohistoria. 4. Enhetskyrkans tid. Stockholm: Verbum i samarbete med Svenska kyrkans forskningsråd.

Morris, R. (2011). Maidens' Garlands: A funeral custom of post-Reformation England. In C. King \& D. Sayer (Eds.), The Archaeology of Post-Medieval Religion (pp. 271-282). Woodbridge: Boydell.

Mytum, H. (2004). Mortuary monuments and burial grounds of the Historic Period. Manuals in archaeological method, theory, and technique. New York: Springer.

Nyberg, J. (2005). Tills döden skiljer oss åt. Gravar och gravskick på Linköpings domkyrkogård under tidigmodern tid. Seminarieuppsats i arkeologi och antikens konst. Stockholm: Stockholm Universitet.

Nyberg, J. (2010). A peaceful sleep and heavenly celebration for the pure and innocent: the sensory experience of death during the long eighteenth century. In: F. Fahlander \& A. Kjellström. Making sense of things: archaeologies of sensory perception (pp. 15-33). Stockholm.

Nyberg, J. (2013). "Oh himmels gyllne pracht". Familjen Brahe och stormaktstidens adliga begravningar. In: R. Gullbrandsson (Ed.), Grevars och bönders tempel: en bok om Brahekyrkan på Visingsö. (pp. 257-275) Jönköpings läns museum..

Nyström Tagesson, E. (2006). Lika inför döden. Social stratifiering vid begravningar vid Linköpings domkyrka 1695-1696. Seminarieuppsats. Historia B, Institutionen för studier av samhällsutveckling och kultur. Linköping: Linköpings Universitet.

Redin, L. (1976). Lagmanshejdan. Dissertation. Lund: Lunds Universitet.

Reeve, J \& Adams, M. (1993). The Spitalfields Project. Volume 1: The Archaeology. Across the Styx. CBA Research Report 85. London: Council for British Archaeology.

Rosén, C. (2004). Stadsbor och bönder. Materiell kultur och social status $i$ Halland från medeltid till 1700-tal. Riksantikvarieämbetet. Arkeologiska undersökningar. Skrifter 53. Lund studies in Medieval Archaeology 35. Lund: Lunds Universitet.

Rosén, C. (2006). Arkeologi och modernitet. In L. Ersgård (Ed.), Det förflutna är att räkna med. En vetenskaplig programskrift från UV (pp. 75-97). Stockholm: Riksantikvarieämbetets förlag.

Sayer, D. (2011). The organization of Post-medieval churchyards, cemeteries and grave plots: variation and religious identity as seen in Protestant burial provision. In C. King \& D. Sayer (Eds.), The archaeology of post-medieval religion (pp. 199-214). Woodbridge: Boydell

Stibéus, M. (1998). En 1600-1700-tals kyrkogård i Kristinehamn. Arkeologisk undersökning i kv. Jupiter 2, Raä 43, Kristinehamn, Värmland. Riksantikvarieämbetet. UV Väst Rapport 1998: 16.

Tagesson, G. (2002). Biskop och stad. Aspekter av urbanisering och sociala rum $i$ medeltidens Linköping. Lund studies in Medieval Archaeology 30. Linköping.

Tagesson, G. (2009). Body, identity and material culture: Linköping Cathedral churchyard in the early modern period. In: Back Danielsson et al. (Eds.), 2009. Döda personers sällskap : gravmaterialens identiteter och kulturella uttryck. On the threshold: burial archaeology in the twenty-first century. (pp. 153-172)

Tagesson, G. (2013). Vore bäst alle huus vore lijka - makt, ideologi och modernitet i den tidigmoderna staden. In: Ersgård (Ed.), Visioner och verklighet - arkeologiska texter om den tidigmoderna staden. Göteborg: Gotarc Series C. Arkeologiska skrifter no. 76

Tagesson, G. \& Westerlund, J. (2004). Domkyrkoparken, Linköping. Gravar från 1100-talet till 1810. Riksantikvarieämbetet. UV Öst. DAFF 2004:1. Linköping.

Tarlow, S. (1999a). Wormie clay and blessed sleep. Death and disgust in later historic Britain. In S. West \& S. Tarlow (Eds.), The familiar past? Archaeologies of later historical Britain (pp. 183198). London: Routledge. 
Tarlow, S. (1999b). Strangely familiar. In S. West \& S. Tarlow (Eds.), The familiar past? Archaeologies of later historical Britain (pp. 263-275). London: Routledge.

Tarlow, S. (2002a). Bodies, selves and individuals. Introduction. In Y.Hamilakis, M. Pluciennik \& S. Tarlow (Eds.), Thinking through the Body. Archaeologies of Corporeality (pp. 23-27). New York: Kluwer Academic/Plenum.

Tarlow, S. (2002b). The aesthetic corpse in nineteenth-century Britain. In Y. Hamilakis, M. Pluciennik \& S. Tarlow (Eds.), Thinking through the Body. Archaeologies of Corporeality (pp. 85-97). New York: Kluwer Academic/Plenum.

Troels-Lund, T.F. (1984) [1879-1901]. Att dö i Norden. Föreställningar om livets slut på 1500-talet. Stockholm: Författarförlaget.

Villstrand, N.E. (2011). Sveriges historia: 1600-1721. Stockholm: Norstedt.

West, S. \& Tarlow, S. (Eds.) (1999). The familiar past: archaeologies of Britain 1550-1950. London: Routledge. 